\title{
IDENTIFIKASI PROFIL BUDAYA ORGANISASI YANG MENDUKUNG IMPLEMENTASI SISTEM PENJAMINAN MUTU PERGURUAN TINGGI
}

\author{
Debby Willar, Jerry Lintong, dan Revleen Kaparang \\ Politeknik Negeri Manado \\ email: debby_willar@yahoo.com
}

\begin{abstract}
Abstrak: Penelitian ini bertujuan untuk mengevaluasi implementasi Sistem Penjaminan Mutu Internal Perguruan Tinggi (SPMI-PT) Politeknik Negeri Manado yang mengacu pada Sistem Manajemen Mutu (SMM) ISO 9001, mengidentifikasi profil budaya organisasi Politeknik Negeri Mando, dan menganalisis hubungan antara implementasi SMM ISO 9001 dan budaya organisasi institusi. Penelitian menggunakan pendekatan kuantitatif dengan instrumen kuesioner. Penelitian menemukan bahwa implementasi delapan prinsip mutu ISO 9001 belum mencapai tingkat efektivitas yang maksimal dan tipe budaya clan mendominasi profil budaya organisasi institusi. Selain itu, juga ditemukan bahwa budaya clan berkorelasi signifikan dengan prinsip mutu kepemimpinan, keterlibatan orang-orang dalam aktivitas institusi, pendekatan proses dalam aktivitas institusi, pendekatan fakta untuk pengambilan keputusan, dan prinisp mutu bubungan yang saling menguntungkan; budaya market berkorelasi signifikan dengan prinsip mutu fokus pada pelanggan; budaya hierarchy berkorelasi signifikan dengan prinsip mutu pendekatan sistem untuk manajemen institusi, dan perbaikan terus-menerus. Hasil penelitian menjadi dasar bagi institusi untuk dapat mengembangkan budaya organisasi yang kuat sebagai pendukung dalam menerapkan SPMI-PTsecara efektif dan meningkat berkelanjutan.
\end{abstract}

Keywords: sistem penjaminan mutu internal, budaya organisasi, perguruan tinggi

\section{IDENTIFICATION OF THE ORGANIZATIONAL CULTURE PROFILE SUPPORTING THE IMPLEMENTATION OF THE HIGHER EDUCATION QUALITY ASSURANCE SYSTEM}

\begin{abstract}
This research was aimed to evaluate the implementation of the Internal Quality Assurance System of the Higher Education (SPMI-PT) of Manado State Polytechnic based on the ISO 9001 Quality Management System (QMS), to identify the organizational culture profile of Manado State Polytechnic, and to examine the relationship between the implementation of ISO 9001 and the culture profile of the institution. Questionnaireswere used in order to achieve the research aims.The study found that the implementation of the eight ISO 9001 principles had not achieved the maximum level of effectiveness, and Clan culture dominated the profile of the organizational culture of Manado State Polytechnic. The research also found that: Clan culture was significantly correlated with the quality principles of Leadership, People Involvement, Process Approach, Factual Approach to Decision Making, and Mutually Beneficial Supplier Relationships;Market culture was significantly correlated with the quality principle of Customer Focus while Hierarchy culture wassignificantly correlated with the quality principles of Systems Approach to Management,and Continual Improvement. The findings are the basis for the institution to be able to develop a strong organizational culture as a driver in implementing the SPMI-PT effectively and sustainably.
\end{abstract}

Keywords: quality assurance system, organizational culture, higher education

\section{PENDAHULUAN}

Renstra 2010-2014 Kemdiknas dan Visi 2014, yaitu "Terselenggaranya layanan prima pendidikan nasional untuk membentuk insan Indonesia cerdas komprehensif", ditanggapi oleh
Direktorat Jenderal Pendidikan Tinggi (DIKTI), antara lain dengan menetapkan Garis Besar Sistem Penjaminan Mutu Perguruan Tinggi. Kegiatan penjaminan mutu perguruan tinggi dilaksanakan dalam sebuah sistem yang disebut 
Sistem Penjaminan Mutu Internal Perguruan Tinggi (SPMI-PT) yang bertujuan untuk menjamin mutu pendidikan tinggi yang diselenggarakan oleh setiap PT, melalui penyelenggaraan Tridharma Perguruan Tinggi, dalam rangka mewujudkan visi serta memenuhi kebutuhan pemangku kepentingan internal dan eksternal perguruan tinggi (Kementerian Pendidikan Nasional dan Kebudayaan, 2011). Dalamrangka menghasilkan lulusan yang profesional yang siap untuk mengaplikasikan keahliannya, sejak tahun 2007 Politeknik Negeri Manado telah menerapkan SPMI-PT dengan mengadopsi Sistem Manajemen Mutu (SMM) ISO 9001. Namun kenyataannya, sampai saat ini belum tampak konsistensi Politeknik Negeri Manado yang signifikan dalam menerapkan SPMI-PT secara efektif dan meningkat berkelanjutan.

Memiliki sertifikat SMM ISO 9001 tidak berarti PT telah mengimplementasi SPMI-PT yang efektif. Untuk dapat efektif penerapannya, diperlukan perubahan budaya organisasi PT yang bersangkutan. Perubahan dari budaya kerja yang tidak efektif dan tidak efisien ke budaya kerja yang bermutu diperlukan untuk mendemonstrasikan keberhasilan dalam menerapkan SPMI-PT. Lingkup pekerjaan pengkajian tentang pengembangan budaya organisasi dalam rangka reformasi birokrasi internal di lingkungan Kemdiknas tahun 2010, juga merumuskan budaya kerja baru yang dapat diimplementasikan secara nyata, serta mengidentifikasi dan memasukkan budaya kerja yang dibutuhkan untuk mendukung kelancaran setiap prosedur Kemdiknas (Kemdiknas, 2010).

Penelitian-penelitian sebelumnya telah melaporkan kajian tentang hubungan antara budaya organisasi dan efektivitas implementasi sistem penjaminan mutu dalam organisasi khususnya institusi pendidikan. Namun, penelitian yang komprehensif tentang topik tersebut belum pernah dilakukan di Indonesia. Keberhasilan penerapan SPMI-PT ISO 9001 memerlukan perubahan budaya organisasi PT, bahkan mengadopsi budaya organisasi yang baru yang berfokus pada pemenuhan kepuasan para pemangku kepentingan internal dan eksternal PT dan pe- ningkatan mutu seluruh proses layanan pendidikan tinggi di semua tingkatan organisasi.

Berdasarkan pada uraian di atas dan kondisi terkini penerapan SPMI-PT ISO 9001 di Politeknik Negeri Manado, tulisan ilmiah ini melaporkan hasil penelitian yang bertujuan untuk (1) mengevaluasi implementasi SPMI-PT ISO 9001 di Politeknik Negeri Manado; (2) mengidentifikasi profil budaya organisasi; dan (3) menganalisis hubungan antara profil budaya organisasi dan implementasi SPMI-PT ISO 9001. Dengan dicapainya tujuan penelitian tersebut, diharapkan dapat untuk membangun budaya organisasi yang kuat sebagai pendukung dalam menerapkan SPMI-PT secara efektif dan meningkat berkelanjutan.Temuan penelitian ini diharapkan akan bermanfaat pada pengembangan kajian fundamental dan orisinil pada bidang ilmu pengukuran dan evaluasi pendidikan secara umum, dan secara khusus dibidang budaya organisasi dan SPMI-PT. Temuan penelitian ini akan pula menjadi modal dasar dan starting point bagi penelitian berikutnya yang berfokus pada penelitian lanjutan tentang profil budaya yang kuat yang mendorong keberhasilan dan efektivitas penerapan SPMI-PT di Indonesia.

Sistem Manajemen Mutu (SMM) ISO 9001 saat ini menjadi sebuah model SMM yang paling banyak direkomendasikan oleh peloporpelopor mutu sebagai sebuah model panduan untuk mengimplementasi manajemen dan kontrol proses yang efektif di berbagai industri dan sektor jasa (McCornac, 2006; Tricker, 2008; Fotopoulos, dkk., 2010; Wahid dkk., 2011). Gamboa dan Mela o (2012), Thonhauser (2005), dan Lawrence dan McCollough (2001) menyatakan bahwa implementasi SMM ISO 9001 di sektor pendidikan memberikan banyak faktor sukses untuk menjamin mutu pendidikan tinggi di negaranya masing-masing. SMM ISO 9001 ini pulalah yang menjadi rekomendasi Kementerian Pendidikan dan Kebudayaan sebagai salah satu model sistem penjaminan mutu internal (SPMI) institusi pendidikan di Indonesia.

Untuk membangun konsep budaya organisasi yang mempengaruhi praktik manajemen mutu atau sebaliknya (Noronha, 2002), semua lini dalam organisasi harus dalam keadaan 
harmoni agar supaya praktik mutu dapat terlaksana (Koh \& Low, 2008). Hal ini berarti, jika manajemen menerapkan pendekatan yang berfokus pada internalisasi nilai-nilai mutu (yang merupakan bagian dari budaya organisasi) pada semua anggota organisasi (Bright \& Cooper, 1993), maka budaya organisasilah yang menciptakan iklim organisasi yang mendukung peningkatan mutu dan atau menumbuhkan iklim mutu; dan pada gilirannya, mengarahkan proses manajemen mutu dan implementasinya dalam mencapai hasil yang bermutu (Noronha, 2002).

Bagi sebuah institusi pendidikan tinggi yang telah mendiagnosis budaya organisasinya dan kemudian memulai perubahan untuk mengembangkan budaya organisasi yang kuat, bukanlah tugas yang mudah. Sandholm (1999) menyatakan bahwa mungkin sulit bagi organisasi untuk mengubah kebiasaan dan perilaku yang biasanya menjadi sebuah budaya mutu yang baru; hal ini membutuhkan usaha dan penyesuaian yang ekstrim. Implementasi sebuah sistem mutu yang efektif dan sukses dalam organisasi termasuk sektor jasa pendidikan, memerlukan perubahan budaya dalam organisasi pendidikan itu sendiri. Cameron dan Quinn (2006) menyarankan 'perubahan budaya' sebagai bentuk keprihatinan dengan membuat perubahan nyata dalam perilaku orang di seluruh tingkatan organisasi. Trice dan Beyer (1993) menjelaskan 'perubahan budaya' dengan merujuk pada perencanaan yang lebih menyeluruh dan substansial terhadap hal-hal yang harus diubah, yang lebih dari sekedar perubahan budaya yang spontan untuk mempertahankan budaya yang sedang terjadi. Perubahan budaya dalam organisasi yang membentuk dan menghasilkan budaya organisasi yang kuat diharapkan dapat mendukung suksesnya implementasi sistem mutu dalam organisasi yang bersangkutan.

Terdapat sejumlah model budaya organisasi yang terkenal yang digunakan untuk mengidentifikasi dan mengukur budaya organisasi. Salah satu model, yaitu Competing Values Framework (CVF), yang dikembangkan oleh peneliti Amerika Kim S. Cameron dan Robert E. Quinn pada tahun 1999, berdasarkan pada hasil riset Quinn dan Rohrbaugh (1983) tentang indikator-indikator yang merepresentasikan pengukuran kinerja organisasi yang efektif. CVF sangat berguna sebagai pedoman untuk mengembangkan budaya organisasi yang efektif dan memfasilitasi perubahan budaya dalam organisasi, sehingga dapat membantu organisasi untuk memahami dirinya sendiri dan dapat membangun lingkungan organisasi yang efektif.

Model budaya organisasi CVF dipilih sebagai model yang paling tepat untuk diterapkan dalam konteks penelitian ini karena kemampuannya dalam mengidentifikasi profil atau tipe budaya organisasi pada organisasi yang belum mengenal secara komprehensif profil budayanya, termasuk mengukur kekuatan profil budaya dan mengidentikasi karakter-karakter yang membentuk profil budaya organisasi.

Model CVF terdiri dari empat jenis budaya organisasi, yaitu Clan, Adhocracy, Hierarchy, dan Market, yang diteorikan untuk menyusun profil budaya dalam berbagai macam konteks organisasi (Choi dkk, 2010). Para penulis ini lebih jauh menjelaskan bahwa suatu organisasi dapat memiliki salah satu faktor yang dominan, yaitu faktor fokus internal (internal focus) atau fokus eksternal (external focus), dan dapat berharap untuk mencapai faktor fleksibilitas dan keleluasaan (flexibility and discretion) atau stabilitas dan kontrol (stability and control). Kombinasi faktor-faktor ini menciptakan empat jenis budaya yang potensial, dimana masing-masing faktor mewakili satu set nilainilai budaya yang berbeda. Empat jenis budaya tersebut (Gambar 1) secara singkat dijelaskan oleh Cameron dan Quinn (2006) seperti tampak pada Gambar 1.

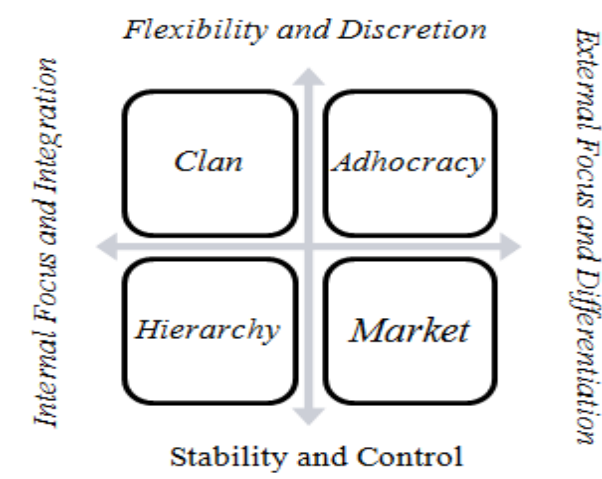

Gambar 1. The Competing Values Framework - CVF (Cameron \& Quinn, 2006) 
Berdasarkan pada model CVF (termasuk faktor-faktor yang terkait), diturunkanlah enam dimensi budaya yang berkaitan dengan setiap jenis budaya-dikenal sebagai Organizational Culture Assessment Instrument (OCAI)-yang menjadi alat ukur untuk mengidentifikasi jenis budaya organisasi beserta dengan sifat dan tipologi disetiap dimensi. Keenam dimensi tersebut aadalah (1) dominant characteristics; (2) organizational leadership; (3) management of employees; (4) organizational glue; (5) strategic emphases; dan (6) criteria of success. Enam dimensi budaya OCAI mewakili iklim budaya dalam suatu organisasi yang merupakan representasi kumulatif budaya organisasi (Rameezdeen \& Gunarathna, 2003).

\section{METODE}

Metode penelitian kuantitatif dipilih untuk mendukung tujuan-tujuan penelitian ini melalui pengumpulan data dengan menggunakan kuesioner. Desain kuesioner terdiri dari dua bagian. Bagian pertama kuesioner didesain untuk mengidentifikasi tipe budaya organisasi Politeknik Negeri Manado dengan menggunakan Organizational Culture Assessment Instrument (OCAI). Bagian kedua kuesioner didesain untuk mengevaluasi tingkat implementasi SPMI-PT ISO 9001 di Politeknik Negeri Manado dengan mengacu pada delapan prinsip mutu ISO 9001.

Seluruh pernyataan dalam kuesioner diklasifikasikan sebagai pernyataan 'tertutup' untuk mendukung variabel-variabel penelitian yang telah ditetapkan untuk diteliti. Sugiyono (2014: 149) mengemukakan bahwa dari setiap pernyataan yang bersesuaian dengan variabel yang diteliti, selanjutnya ditentukan indikator yang akan diukur yang diturunkan dari teori yang mendukungnya. Untuk mengevaluasi tingkat implementasi SPMI-PT ISO 9001, digunakan format skala berdasarkan pada 'an unbalanced itemized rating scale'. Format skala terdiri atas 1 sampai dengan 5 yang menggambarkan indikator tingkat efektivitas implementasi sistem mutu tersebut.

Bagian kuesioner yang mengukur budaya organisasi, format skala didesain berdasarkan pada 'an unbalanced itemized rating scale', juga terdiri atas skala 1 sampai dengan 5. Pengukuran variabel budaya yang berdasarkan an unbalanced itemized rating scale menyediakan fleksibilitas untuk menentukan jumlah poin skala sebagaimana yang dibutuhkan (Sekaran \& Bougie, 2009). Pengujian validitas konstruk instrumen penelitian (kuesioner) dilakukan melalui studi awal, yaitu konsultansi dengan Wakil Manajemen Mutu (WMM) dan Auditor Mutu Internal sebagai orang yang berkompeten dalam evaluasi implementasi SPMI-PT ISO 9001. Setelah pengujian konstruk kuesioner, dilanjutkan dengan uji coba kuesioner pada 28 responden (dosen dan dan pegawai). Hasil uji coba kuesioner menjadi dasar dilakukannya revisi minor kuesioner untuk lebih memastikan validitas konstruk kuesioner sebelum digunakan untuk pengumpulan data.

Pada kegiatan pengumpulan data, 400 kuesioner telah didistribusikan ke dosen dan pegawai administrasi Politeknik Negeri Manado. Kuesioner yang dikembalikan berjumlah 330 kuesioner; 14 kuesioner tidak lengkap datanya, sehingga total kuesioner yang dapat dianalisis berjumlah 316 kuesioner, merepresentasikan $61,6 \%$ responden (total jumlah dosen dan pegawai 513 orang) yang berpartisipasi. Responden terdiri dari 199 orang dosen dan 117 orang pegawai administrasi. Sejumlah 13 responden yang telah bekerja dalam kurun waktu 1 sampai dengan 5 tahun, 71 orang telah bekerja selama lebih dari 5 tahun dan sampai dengan 10 tahun, 70 orang telah bekerja selama lebih dari 10 tahun dan sampai dengan 15 tahun, 89 orang telah bekerja selama lebih dari 15 tahun dan sampai dengan 20 tahun, dan 73 orang telah bekerja lebih dari 20 tahun.

Pengujian reliabilitas kuesioner dilakukan dengan teknik analisis Cronbach's alpha untuk mengevaluasi internal konsistensi butirbutir pernyataan kuesioner. Hasil analisis Cronbach's alpha $=0,967$ untuk jumlah butir $=32$ dan jumlah responden $=316$. Nilai Cronbach's alpha mendekati 1 mengartikan internal konsistensi butir-butir pernyataan yang tinggi, sehingga kuesioner dapat diterima sebagai instrumen yang reliable pada penelitian ini.Cronbach's alpha yang melebihi 0,80 dianggap baik, di 
antara 0,70 dan 0,80 dapat diterima sedangkan dibawah 0,70 dianggap kurang baik (Sekaran \& Bougie 2009).

Analisis data menggunakan teknik statistik deskriptif yang dilakukan dengan mengambil nilai rata-rata dari setiap pernyataan prinsip mutu, dimana setiap prinsip mutu memiliki lima tingkatan implementasi. Tingkat implementasi 5 untuk mean $=4,51-5,00$; tingkat 4 untuk mean $=3,51-4,00$; tingkat 3 untuk mean $=2,51-$ 3,50; tingkat 2 untuk mean $=1,51-2,50$; tingkat 1 untuk mean< 1,50. Pernyataan-pernyataan yang berkaitan dengan profil budaya organisasi institusi, dianalisis dengan menggunakan kertas kerja Organizational Culture Assessment Instrument-OCAI dan diagram Competing Value Framework-CVF. Analisis data untuk mengetahui hubungan antara variabel OCAI-CVF (sebagai variabel $x$ - variabel bebas) dan variabel tingkat implementasi delapan prinsip mutu ISO 9001 (sebagai variabel $y$ - variabel terikat) menggunakan teknik korelasi Pearson. Analisis Pearson'sr merupakan suatu analisis untuk mengetahui kekuatan dan arah hubungan yang linier di antara dua atau lebih variabel yang kontinu (Allen \& Bennett, 2010: 165).

\section{HASIL DAN PEMBAHASAN}

Analisis bagian pertama kuesioner menggunakan kertas kerja Organizational Culture Assessment Instrument (OCAI) dengan menghitung nilai rata-rata di setiap dimensi budaya organisasi, yang pada akhirnya membentuk profil budaya organisasi Politeknik Negeri Manado. Analisis profil budaya yang berdasarkan pada nilai rata-rata penilaian terhadap pernyataan dimensi budaya organisasi oleh 316 responden, selanjutnya diinterpretasi dan dibahas dengan menggunakan pustaka utama Cameron dan Quinn (2006, 2011).

Seperti terlihat dalam Tabel 1, nilai ratarata OCAI di setiap dimensi budaya membentuk profil budaya Politeknik Negeri Manado, terdiri dari empat jenis budaya organisasi: Clan, Adhocrcay, Market, dan Hierarchy. Dapat dilihat pula dalam Tabel 1, pada hampir seluruh dimensi budaya organisasi, budaya Clan lebih tinggi nilai rata-ratanya dibandingkan dengan ketiga jenis budaya lainnya, kecuali pada dimensi Dominant Characteristics didominasi oleh budayaHierarchy. Ploting total nilai ratarata keempat jenis budaya pada diagram Competing Values Framework (CVF) menunjukkan keseluruhan profil budaya organisasi Politeknik Negeri Manado. Total nilai rata-rata yang tidak jauh berbeda antara satu nilai dengan nilai lainnya mengartikan keempat jenis budaya cenderung sama kuat, namun budaya $\operatorname{Clan}($ mean $=$ 3,72) sedikit lebih kuat dari budaya Adhocracy $($ mean $=3,36)$, Market $($ mean $=3,49)$ dan Hierarchy (mean $=3,51$ ). Hal ini menunjukkan pula institusi sedang fokus pada aspek internal dan integrasi proses-prosesnya.

Penonjolan budaya hierarchy sebagai budaya yang dominan mengartikan institusi sebagai tempat yang sangat terkontrol dan terstruktur. Pegawai administrasi dan dosen melaksanakan tugas kerjanya berdasarkan pada prosedur formal. Kondisi ini sejalan dengan sedang dikembangkannya dan diterapkannya standar operasional prosedur (SOP) pada interaksi manajemen, proses pendidikan dan komunikasi dalam institusi.

Penonjolan budaya clan pada dimensi kepemimpinan (Organizational Leadership) mengartikan tipe pemimpin dalam instiusi yang pada umumnya dianggap berciri khas mentoring, memfasilitasi, dan mengasuh. Demikian pula untuk dimensi pengelolaan karyawan (Management of Employee), responden menanggapi sebagaigaya manajemen clan yang ditandai dengan tipologi kerja sama tim, konsensus, dan partisipasi. Budaya clan yang ditanggapi oleh sebagian besar responden mendominasi tipe kepemimpinan dan gaya pengelolaan karyawan, mendominasi pula dimensi budaya yang mempersatukan seluruh elemen dalam institusi (OrganizationalGlue). Perekat yang dianggap dapat mempersatukan institusi adalah loyalitas dan rasa saling percaya serta komitmen yang tinggi.

Sifat dan tipologi budaya clan tetap ditanggapi oleh sebagian besar responden sebagai jenis budaya yang mendominasi cara-cara institusi membangun strateginya (Strategic Emphases yaitu menekankan pada pembangunan manusia, kepercayaan yang tinggi, keterbukaan, 
Tabel 1.Nilai Keseluruhan OCAI Politeknik Negeri Manado ( $=316)$

\begin{tabular}{llcccc}
\hline \multirow{2}{*}{ No. } & \multirow{2}{*}{ 6 Dimensi Budaya Organisasi } & \multicolumn{4}{c}{ Nilai Rata-rata (Mean Value) } \\
\cline { 3 - 6 } & & Clan & Adhocracy & Market & Hierarchy \\
\hline 1. & Dominant Characteristics & 3,63 & 3,17 & 3,52 & 3,70 \\
2. & Organizational Leadership & 3,68 & 3,30 & 3,41 & 3,49 \\
3. & Management of Employee & 3,60 & 3,34 & 3,41 & 3,52 \\
4. & Organizational Glue & 3,86 & 3,65 & 3,68 & 3,63 \\
5. & Strategic Emphases & 3,72 & 3,46 & 3,51 & 3,44 \\
6. & Criteria of Success & 3,81 & 3,26 & 3,40 & 3,27 \\
\hline & Total Nilai Rata-rata Profil Budaya Organisasi & 3,72 & 3,36 & 3,49 & 3,51 \\
\hline
\end{tabular}

Tabel 2. Profil Budaya Organisasi Politeknik Negeri Manado

\begin{tabular}{llc}
\hline \multicolumn{1}{c}{$\begin{array}{c}\text { Dimensi } \\
\text { Budaya }\end{array}$} & \multicolumn{1}{c}{$\begin{array}{c}\text { Sifat dan Tipologi / Nilai-nilai } \\
\text { Jenis Budaya }\end{array}$} & $\begin{array}{c}\text { Jenis Budaya } \\
\text { yang Dominan }\end{array}$ \\
\hline $\begin{array}{l}\text { Karakter yang Dominan } \\
\text { Dominant Characteristics }\end{array}$ & $\begin{array}{l}\text { Controlled and structured - institusi sebagai tempat yang sangat } \\
\text { terkontrol dan terstruktur }\end{array}$ & Hierarchy \\
Kepemimpinan & Mentoring, facilitating, or nurturing - tipe pemimpin dalam & Clan \\
Organizational & institusi pada umumnya dianggap berciri khas mentoring, & Clan \\
Leadership & memfasilitasi, dan mengasuh & Clan \\
Pengelolaan Karyawan & Teamwork, consensus, and participation - gaya manajemen & \\
Management of & dalam institusi ditandai dengan kerja sama tim, konsensus, dan & \\
Employees & partisipasi & Clan \\
Perekat Organisasi & Loyalty and mutual trust - perekat yang dianggap dapat & \\
Organizational Glue & mempersatukan institusi berciri khas loyalitas dan rasa saling & \\
Penekanan Strategi & percaya & Human development, high trust, openness - institusi \\
Strategic Emphases & membangun strateginya berdasarkan pada pembangunan & \\
Kriteria untuk Sukses & manusia, kepercayaan yang tinggi, keterbukaan, dan partisipasi & \\
Criteria of Success & Development of human resources, teamwork, and concern for & Clan \\
& people - kesuksesan institusi adalah atas dasar pengembangan & \\
& sumber daya manusia, kerja sama tim, komitmen karyawan, dan & \\
\hline
\end{tabular}

Pustaka: Cameron dan Quinn (2006, 2011)

dan partisipasi. Karakter kuat budaya clan yang menganalogikan organisasi sebagai sebuah keluarga, ditanggapi pula oleh para responden sebagai jenis budaya yang mendominasi dimensi kriteria kesuksesan (Criteria of Success), di mana responden menilai kesuksesan institusi adalah atas dasar pengembangan sumber daya manusia, kerja sama tim, komitmen karyawan, dan saling peduli.Komitmen sebagai salah satu nilai budaya institusi pendidikan. Hal ini melengkapi pula temuan Suriansyah (2014:358) yang menyatakan bahwa budaya sekolah memiliki hubungan dengan komitmen dan komitmen merupakan perantara hubungan budaya sekolah dengan kinerja guru dan hubungan komunikasi dengan kinerja guru. Nilai komitmen sebagai salah satu kriteria kesuksesan institusi pendidikantinggi mencakup pula pengaruh komitmen terhadap motivasi berprestasi mahasiswa, sebagaimana pernyataan hasil penelitian Dirwan (2014:379).

Tabel 2 merangkum profil budaya organisasi Politeknik Negeri Manado berdasarkan data responden, dengan mengadopsi model budaya organisasi CVF - OCAI.

Dominasi budaya clan dan hierarchy di Politeknik Negeri Manado kenyataannya sejalan dengantemuan sebuah studi budaya organisasi di perguruan tinggi, dimana budaya Hierarchy umumnyaeksis di kelompok staf admi- 
nistrasi sedangkan gabungan budaya clan - hierarchy eksis dikelompok staf pengajar (Trivellas \& Dargenidou, 2009). Sifat dan tipologi budaya hierarchyyang muncul sebagai salah satu jenis budaya yang menyatakan bahwa perekat yang mempersatukan organisasi adalah peraturan dan kebijakan formal, juga bersesuaian dengan kondisi terkini dalam institusi di mana sedang diterapkannya standar operasional prosedur pada sebagian besar proses layanan pendidikan dan operasi penunjang layanan pendidikan.

Identifikasi profil budaya organisasi serta memahami sifat dan tipologi profil budaya organisasi adalah langkah-langkah strategis untuk diterapkan oleh organisasi yang memiliki sistem manajemen mutu. Dalam penelitian ini, profil budaya organisasi clan-hierarchy (beserta dengan nilai-nilai budayanya) memberikan gambaran yang jelas bagi pimpinan dan staf untuk melakukan perubahan dan menetapkan langkah-langkah strategis dan prioritas untuk membangun budaya organisasi yang kuat.
Analisis bagian kedua kuesioner mengukur tingkat implementasi SPMI-PT ISO 9001 di Politeknik Negeri Manado. Dasar pengukuran adalah pada penerapan delapan prinsip mutu ISO 9001. Analisis dilakukan dengan mengambil nilai rata-rata dari setiap pernyataan prinsip mutu, di mana setiap prinsip mutu memiliki lima tingkatan implementasi.

Data pada Tabel 3 menampilkan penerapan prinsip-prinsipp (ada delapan prinsip) dengan level implementasinya. Misalnya, (P5) 'pendekatan sistem untuk manajemen institusi' (berada pada tingkat 3 ) berarti proses bisnis institusi sedang dikembangkan sebagai bagian dari Sistem Manajemen Mutu (SMM). Implementasi prinsip (P1) 'fokus pada pelanggan' (berada pada tingkat 4) menunjukkan bahwa institusi sedang memahami kebutuhan pelanggan dan berusaha memenuhinya. Prinsip (P2) 'kepemimpinan' (tingkat 4) berarti para pimpinan berkomitmen dengan melibatkan diri secara pribadi.

Tabel 3. Tingkat Implementasi SMM ISO 9001 di Politeknik Negeri Manado (N=316)

\begin{tabular}{lcccc}
\hline \multicolumn{1}{c}{ Prinsip Manajemen Mutu } & Mean & $\begin{array}{c}\text { Std. } \\
\text { Deviation }\end{array}$ & 95\% CI & $\begin{array}{c}\text { Tingkat } \\
\text { Implementasi }\end{array}$ \\
\hline Fokus pada pelanggan (P1) & 3,69 & 0,89 & $3,56-3,79$ & 4 \\
Kepemimpinan (P2) & 3,77 & 1,24 & $3,62-3,89$ & 4 \\
Keterlibatan orang-orang dalam aktivitas institusi (P3) & 3,55 & 1,30 & $3,41-3,70$ & 4 \\
Pendekatan proses dalam aktivitas institusi (P4) & 3,72 & 1,01 & $3,60-3,83$ & 4 \\
Pendekatan sistem untuk manajemen institusi (P5) & 3,47 & 1,16 & $3,33-3,59$ & 3 \\
Perbaikan terus-menerus (P6) & 3,70 & 1,03 & $3,57-3,81$ & 4 \\
Pendekatan fakta untuk pengambilan keputusan (P7) & 3,75 & 1,07 & $3,62-3,86$ & 4 \\
Hubungan yang saling menguntungkan (P8) & 3,80 & 1,09 & $3,68-3,92$ & 4 \\
\hline
\end{tabular}

Catatan: Tingkat implementasi: 5 untuk mean $=4,51-5,00 ; 4$ untuk mean = 3,51-4,00; 3 untuk mean = 2,51 3,$50 ; 2$ untuk mean =1,51 - 2,50; 1 untuk mean< 1,50.

Tabel 4. Uji Korelasi Budaya Organisasi dan Implementasi SMM ISO 9001

\begin{tabular}{|c|c|c|c|c|}
\hline Prinsip Manajemen Mutu Budaya Organisasi & $\begin{array}{l}\text { Clan } \\
\text { Type }\end{array}$ & $\begin{array}{c}\text { Adhocracy } \\
\text { Type }\end{array}$ & $\begin{array}{c}\text { Market } \\
\text { Type }\end{array}$ & $\begin{array}{c}\text { Hierarchy } \\
\text { Type }\end{array}$ \\
\hline Fokus pada Pelanggan & $0,452 * *$ & $0,440 * *$ & $0,474 * *$ & $0,423 * *$ \\
\hline Kepemimpinan & $0,475 * *$ & $0,462 * *$ & $0,472 * *$ & $0,456 * *$ \\
\hline Keterlibatan Orang-orang dalam Aktivitas Institusi & $0,462 * *$ & $0,385 * *$ & $0,439 * *$ & $0,418 * *$ \\
\hline Pendekatan Proses dalam Aktivitas Institusi & $0,473 * *$ & $0,448 * *$ & $0,426 * *$ & $0,468 * *$ \\
\hline Pendekatan Sistem untuk Manajemen Institusi & $0,472 * *$ & $0,446 * *$ & $0,487 * *$ & $0,509 * *$ \\
\hline Perbaikan Terus-menerus & $0,457 * *$ & $0,462 * *$ & $0,434 * *$ & $0,464 * *$ \\
\hline Pendekatan Fakta untuk Pengambilan Keputusan & $0,468 * *$ & $0,388 * *$ & $0,375 * *$ & $0,421 * *$ \\
\hline Hubungan yang Saling Menguntungkan & $0,473 * *$ & $0,470 * *$ & $0,465 * *$ & $0,438 * *$ \\
\hline
\end{tabular}
Note: ** Correlation is significant at the 0.01 level (2-tailed) 
Analisis lewat uji korelasi Pearson bertujuan untuk menguji korelasi antara tingkat implementasi delapan prinsip mutu ISO 9001 dan profil budaya organisasi. Uji korelasi dilakukan untuk menganalisisjenis budaya tertentu yang memengaruhi tingkat implementasi prinsip mutu ISO 9001 secara signifikan sebagaimana ditunjukkan pada Tabel 4. Hasil analisis korelasi antara budaya clan dengan beberapa prinsip mutu ISO 9001 tersebut mengindikasikan adanya hubungan yang signifikan.

Korelasi yang kuat dan signifikan tersebut dalam penerapan kerangka Competing $\mathrm{Va}$ lues Farmework (CVF) pada aspek Total Quality Management (TQM) menyoroti hal-hal yang berkaitan dengan: pemberdayaan orang-orang dalam institusi, team building, keterlibatan karyawan, pengembangan sumber daya manusia, dan komunikasi yang terbuka. Bagi institusi yang sedang menerapkan SPMI-PT ISO 9001, dominasi budaya Clan memperkuat keterlibatan sumber daya manuasianya dengan menekankan komitmen dan moral tinggi terhadap mutu layanan pendidikan. Partisipasi semua orang dalam menerapkan SPMI-PT dilakukan dalam komunikasi yang mudah dan terbuka agar semua orang dapat saling memahami sistem mutu tersebut. Selain itu, budaya Clan yang flexibilityoriented mendukung pula desentralisasi dan diferensiasi yang dapat mempermudah implementasi sistem mutu sebagaimana hal ini menjadi keinginan bersama orang-orang dalam organisasi (Cheng, 2005). Hal ini dapat membantu meminimalisir anggapan bahwa ISO 9001 adalah SMM yang kaku dan sulit diterapkan.

Tabel 4 menunjukkan juga hubungan yang positif dan signifikan terjadi antara tipe budaya Market dengan prinsip mutu 'fokus pada pelanggan'. Hal ini mengisyaratkan bahwa tepat bagi institusi untuk meningkatkan layanan pendidikan dan pendukung operasi pendidikan guna memenuhi persyaratan pelanggannya dengan menekankan pada sifat dan tipologi budaya Market. Penerapan budaya Market dalam kerangka Competing Values Farmework (CVF) pada aspek Total Quality Management (TQM) menyoroti hal-hal yang berkaitan dengan: mengukur dan mengevaluasi keinginan/persyaratan pelanggan, meningkatkan produktivitas, menciptakan kemitraan eksternal, meningkatkan daya saing, dan melibatkan pelanggan dan pemasok (Cameron dan Quinn, 2011) dalam menetapkan persyaratan layanan dan produk institusi.

Budaya hierarchy yang mendominasi dimensi karakter budaya yang dominan dalam institusi tidaklah mengherankan jika dipahami pengaruh budaya Asia yang nampak pada para manajemen yang membuat keputusan strategis bagi institusi, sementara dosen dan pegawai yang mengikuti keputusan disertai dengan loyalitas dan ketaatan. Pada uji korelasi jenis budaya ini dengan implementasi ISO 9001 di institusi, budaya hierarchy menopang implementasi sistem mutu ini dalam kondisi yang stabil dan terkontrol. Pengelolaan SPMI-PT Politeknik Negeri Manado yang berbasis SMM ISO 9001 jelas terdefinisi dalam pedoman dan prosedur mutu yang mengarahkan dosen dan pegawai bekerja menuju budaya mutu dan pada akhirnya mengadopsi Total Quality Management (TQM).

Penelitian ini menunjukkan bahwa dominasi budaya clan dan hierarchy dalam menunjang implementasi SPMI-PT ISO 9001. Hal ini memverifikasi temuan Choi dkk (2010) bahwa tidak ada satu jenis budaya yang tepat dan tunggal yang harus dimiliki oleh organisasi agar lebih efektif atau berhasil karena ada banyak subunit dalam suatu organisasi yang memiliki budaya yang berbeda pada tingkat organisasi yang berbeda pula (Cameron dan Quinn, 2006).

Dominasi budaya clan dan hierarchy dalam institusi mengarahkan institusi pada saat ini untuk fokus secara internal dalam membangun dan mengembangkan nilai-nilai, sifat dan tipologi kedua jenis budaya ini guna meningkatkan efektivitas implementasi SPMI-PT ISO 9001. Aspek lainnya adalah bahwa elemen-elemen budaya clan dapat memandu institusi dalam membangun komunikasi baik internal maupun eksternal dengan para pelanggan/pemangku kepentingan lainnya dan komunitas terkait guna kelangsungan hubungan jangka panjang. Oleh karena itu, diyakini bahwa SPMI-PT akan sukses diterapkan dalam lingkungan institusi yang 
berwawasan customer oriented dan human resources development serta empowerment.

Korelasi profil budaya organisasi dengan kondisi terkini implementasi SPMI-PT ISO 9001 di institusi menghasilkan temuan berupa strategi prioritas untuk memimpin dan mengelola orang-orang dalam organisasi sehingga dapat secara efektif dalam menerapkan SPMI-PT serta menjalin kerja sama eksternal. Hal ini berarti bahwa budaya organisasi memiliki hubungan yang kuat dengan implementasi SPMI-PT ISO 9001 serta dapat mendukung efektivitas implementasi SPMI-PT di Politeknik Negeri Manado.

\section{PENUTUP}

\section{Simpulan}

Studi empiris yang bertujuan mengevaluasi implementasi Sistem Penjaminan Mutu Internal Perguruan Tinggi (SPMI-PT) Politeknik Negeri Manado yang mengacu pada Sistem Manajemen Mutu (SMM) ISO 9001 menghasilkan temuan bahwa: (1) institusi telah memahami kebutuhan pelanggan dan sedang berusaha memenuhinya (prinsip mutu fokus pada pelanggan); (2) komitmen pimpinan ditunjukkan dengan melibatkan diri secara pribadi (prinsip mutu kepemimpinan); (3) keterlibatan pimpinan dan staf nampak pada program-program tertentu (prinsip mutu keterlibatan orang-orang dalam aktivitas institusi); (4) seluruh aktivitas dan sumber daya pendukung aktivitas dikelola dalam bentuk proses-proses namun luaran aktivitas belum seluruhnya menjadi lebih efisien (prinsip mutu pendekatan proses dalamaktivitas institusi); (5) proses-proses bisnis institusi sedang dikembangkan sebagai bagian dari SMM (prinsip mutu pendekatan sistem untuk manajemen institusi); (6) perbaikan kinerja institusi telah dipahami dan diterapkan sepenuhnya (prinsip mutu perbaikan terus-menerus); (7) pengambilan keputusan berdasarkan rekaman data dari setiap unit kerja (prinsip mutu pendekatan fakta untuk pengambilan kesimpulan); dan (8) hubungan institusi dengan mitra selalu dievalusi untuk ditinjau kembali (prinsip mutu hubungan yang saling menguntungkan).
Tujuan penelitian untuk mengidentifikasi profil budaya organisasi Politeknik Negeri Manado menghasilkan temuan bahwa jenis budaya Clan dan Hierarchy yang mendasari dosen dan pegawai administrasi dalam berpikir dan melakukan tugas-tugasnya serta saling mendukung satu dengan lainnya sehingga memungkinkan institusi untuk mengoperasikan proses layanan pendidikan dan operasi penunjang layanan pendidikan secara efektif.Profil budaya gabungan Clan - Hierarchy (beserta dengan nilai-nilai budayanya) menjadi sebuah gambaran yang jelas bagi Politeknik Negeri Manado untuk melakukan perubahan dan menetapkan langkah-langkah strategis dan prioritas untuk membangun budaya organisasi yang kuat.

Tujuan penelitian untuk menganalisis hubungan antara implementasi SMM ISO 9001 di Politeknik Negeri Manado dan budaya organisasi institusi menghasilkan temuan: (1) budaya Clan berkorelasi signifikan dengan prinsip mutu: kepemimpinan, keterlibatan orang-orang dalam aktivitas institusi, pendekatan proses dalam aktivitas institusi, pendekatan fakta untuk pengambilan keputusan, dan prinisp mutu hubungan yang saling menguntungkan; (2) budaya market berkorelasi signifikan dengan prinsip mutu fokus pada pelanggan; sedangkan (3) budaya hierarchy berkorelasi signifikan dengan prinsip mutu pendekatan sistem untuk manajemen institusi dan prinisp mutu perbaikan terus-menerus. Berdasarkan hasil identifikasi profil budaya organisasi, analisis hubungan profil budaya organisasi dan tingkat implementasi ISO 9001 di Politeknik Negeri Manado, dapat direkomendasikan bahwa perlu adanya integrasi sifat dan tipologi budaya Clan - Hierarchy serta pengembangan nilai-nilai budaya Market, sebagai suatu strategi manajemen guna mendukung dan meningkatkan konsistensi dan efektivitas implementasi SPMI-PT ISO 9001 di Politeknik Negeri Manado.

\section{Saran}

Sebagai tindak lanjut temuan penelitian ini, disarankan untuk Pimpinan Puncak Politeknik Negeri Manado hendaknya memulai membangun budaya organisasi Politeknik Negeri 
Manado yang kuat yang menekankan gabungan dari nilai-nilai jenis budaya Clan - Hierarchy serta mengembangkan nilai-nilai budaya Market pada semua tingkatan organisasi dalam institusi. Meskipun akan menemui rintangan dalam mengembangkan budaya yang akan mendukung implementasi SPMI-PT ISO 9001. Hal ini dapat diatasi dengan menyusun dan menerapkan strategi yang akurat dan tepat yang mengarah ke perubahan budaya (culture change). Penyusunan strategi yang dimaksud dapat berbentuk langkah-langkah teknis yang tertuang dalam peraturan internal institusi, standar operasional prosedur, dan dokumen action plan lainnya untuk melengkapi dokumen SPMI-PT yang telah ada, sehingga dapat memudahkan institusi dalam mengembangkan budaya organisasi yang kuat untuk mendukung implementasi SPMI-PT ISO 9001 yang efektif.

\section{UCAPAN TERIMA KASIH}

Peneliti mengucapkan terima kasih kepada Direktorat Penelitian dan Pengabdian Kepada Masyarakat Ditjen DIKTI sebagai penyelenggara Program Desentralisasi Tahun 2014 untuk Penelitian Skim Fundamental ini dan kepada Tim Editor, Staf, dan Mitra Bestari Jurnal Cakrawala Pendidikan yang telah memfasilitasi penerbitan artikel dari hasil penelitian tersebut.

\section{DAFTAR PUSTAKA}

Allen, P. \& Bennet, K. 2010. PASW Statistics by SPSS: A practical guide, version 18.0. South Melbourne: Cengage Learning Australia.

Bright, K. \& Cooper,C. L. 1993. "Organizational Culture and the maNagement of Quality: Towards a New Framework". Journal of Managerial Psychology, 8 (6), hlm.21-27.

Cameron, K. S. \& Quinn,R. E. 2006. Diagnosing and Changing Organizational Culture: Based on the Competing Values Framework. Revised ed. San Fransisco: Jossey-Bass.

Cameron, K. S. \& Quinn, R. E. 2011. Diagnosing and Changing Organizational
Culture: Based on the Competing Values Framework. Third ed. San Fransisco: Jossey-Bass.

Cheng, W. M. 2005. A Study on the Organizational Culture and Total Quality Management Implementation of Construction Companies in Hong Kong, Department of Real Estate and Construction, The University of Hong Kong, Hong Kong.

Choi, Y. S., Seo, M.,Scott, D. \& Martin, J. 2010. "Validation of the Organizational Culture Assessment Instrument: An Application of the Korean Version", Journal of Sport Management, 24, hlm. 169-189.

Dirwan, A. 2014. "Pengaruh Kualitas Pelayanan dan Komitmen Mahasiswa terhadap Motivasi Berprestasi Mahasiswa Perguruan Tinggi Swasta",Cakrawala Pendidikan, XXXIII (3), hlm. 379-391.

Fotopoulos, C. V., Psomas, E. L. \& Vouzas, F. K. 2010."Investigating Total Quality Management Practice's Inter-relationships in ISO 9001:2000 Certified Organisations", Total Quality Management, 21 (5), hlm. 503-515.

Gamboa, A. J. \& Mela o, N. F. 2012. "The Impacts and Success Factors of ISO 9001 in Education Experiences from Portuguese Vocational Schools", International Journal of Quality \& Reliability Management, 29 (4), hlm.384-401.

Kemendiknas-Kementerian Pendidikan Nasional. 2010. Ringkasan Kegiatan Reformasi Birokrasi Internal Tahun 2010.

Kementerian Pendidikan Nasional dan Kebudayaan, 2011. Garis Besar Sistem Penjaminan Mutu Perguruan Tinggi. Direktorat Jenderal Pendidikan Tinggi, Direktorat Pembelajaran dan Kemahasiswaan.

Koh, T. Y. \& Low, S. P. 2008. "Organizational Culture and TQM implementation in Construction Firm in Singapore", Construction Management and Economics, 26 (3), hlm. 237-248.

Lawrence, J. J. \& McCollough, M. 2001. “A Conceptual Framework for Guaranteeing 
Higher Education", Quality Assurance in Education, 9 (3), hlm.139-152.

McCornac, D. C. 2006. "The implementation of ISO 9000 in Vietnam: Case Studies from the Footwear Industry". International Business \& Economics Research Journal, 5 (2), hlm.77-86.

Noronha, C. 2002. The Theory of Culture-Specific Total Quality Management: Quality Management in Chinese Regions. Hampshire: Palgrave.

Quinn, R. E. \& Rohrbaugh, J. 1983. “A Spatial Model of Effectiveness Criteria: Toward a Competing Values Approach to Organizational Analysis", Management Science, 29 (3), hlm.363-377.

Rameezdeen, R. \& Gunarathna, N. 2003. "Disputes and Construction Industry Cultures". AACE International Transactions, ProQuest Central, CD241.

Sandholm, L. 1999. "Trendy Versus Effective Quality Strategies". The TQM Magazine, 11 (6), hlm.437-444.

Sekaran, U. \& Bougie, R. 2009. Research Methods for Business: A Skill-Building Approach. Fifth ed. Chichester-UK: Wiley.

Sugiyono. 2014. Metode Penelitian Kombinasi (Mixed Methods). Bandung: Alfabeta.
Suriansyah, A. 2014. "Hubungan Budaya Sekolah, Komunikasi, dan Komitmen Kerja terhadap Kinerja Guru Sekolah Dasar Negeri". Cakrawala Pendidikan, XXXIII (3), hlm.358-367.

Thonhauser, Th. L. 2005. "Factors that Relate to the Successful Implementation of ISO 9000 in Education: A Comparison between the US and England". PhD Thesis, College of Education, The Graduate School, The Penssylvania State University, USA.

Trice, H. M. \& Beyer J. M. 1993.The cultures of work organizations. Englewood Cliffs, N.J: Prentice Hall.

Tricker, R. 2008. ISO 9001:2000 for Small Business. Third Edition ed. Oxford: Butterworth-Heinemann.

Trivellas, P. \& Dargenidou, D. 2009. "Organisational Culture, Job Satisfaction and Higher Education Service Quality: The Case of Technological Educational Institute of Larissa". The TQM Journal, 21 (4), hlm.382-399.

Wahid, R. A., Corner, J. \& Tan, P.L. 2011. "ISO 9000 Maintenance in Service Organisations: Tales from Two Companies", International Journal of Quality \& Reliability Management, 28 (7), hlm.735-757. 